\title{
"Dari Ainal Madhiah Ke Si Kakek Merah" Ethnography of the Community Response Towards Covid-19 Pandemic
}

\author{
Muhammad Sahlan ${ }^{1,}$ Ade Ikhsan Kamil ${ }^{2 *}$, Iromi Ilham ${ }^{3}$, Khairul Amin ${ }^{4}$ \\ ${ }^{l}$ Sociology of Religion Department, Philosophy and Religion Faculty, Universitas Islam Negeri Ar-Raniry, Banda, \\ Aceh, Indonesia \\ ${ }^{2}$ Anthropology Department, Faculty of Social and Political Science, Universitas Malikussaleh, Lhokseumawe, Aceh, \\ Indonesia \\ ${ }^{3}$ Anthropology Department, Faculty of Social and Political Science, Universitas Malikussaleh, Lhokseumawe, Aceh, \\ Indonesia
}

${ }^{4}$ Islamic Senior Highschool 1 Pidie, Aceh Indonesia

*Corresponding author. Email: ade.ikhsan.kamil@unimal.ac.id

\begin{abstract}
This paper aims to explain the socio-cultural dynamics of the Acehnese in responding to the Covid-19 pandemic as a disaster that has a global impact. I argue that the general response of the Acehnese community can be seen from the representation of masks, stickers and scatter. The representation of this response to Covid-19 shows that the Acehnese people have lost their vision of a future such as a socio-cultural order in organizing their life cycle. Even if we look at the historically or trajectory starting from the Aceh war with the Netherlands and the Covid 19 pandemic, it shows that the harmonious order between the boundaries of the world and the hereafter has not remained in the cultural memory of society. I use ethnographic methods in the data collection process to see the extent of the relationship between the general public responses to survival against Covid 19. Based on the analysis that the author has conducted on ethnographic data; I conclude that currently the people of Aceh are experiencing confusion as to what choices should be made in the face of conditions that are full of uncertainty due to the Covid 19 pandemic. The confusion is seen from the response to disaster mitigation efforts. in order to maintain people's lives, namely by means of masks, the phenomenon of stickers and the spread of Slots Game.
\end{abstract}

Keywords: Community Responses, Covid-19, Ethnography, Culture

\section{INTRODUCTION}

Soon after the announcement that one of the Covid 19 suspects who died on March 28, 2020 in the city of Lhokseumawe, Aceh Province. People, local governments are starting to believe that Covid-19 is a global disaster as justified by WHO. This belief has awakened the awareness of various groups in Acehnese society in general, from the local government, the legislature, academics, religious authorities and economic actors, both micro and macro.

Even though disaster is not something strange to the people of Aceh. History records that disasters often become history in the journey of civilization in
Acehnese society, from the colonial period to the present. Disasters such as Covid-19 are also categorized as natural disasters, as well as warfare which is classified as a social disaster and there is a classification of technological disasters [1, p. 5]

However, the response of the Acehnese people toward Covid-19 looks so different compared to various other disasters that have occurred, for example in the past 200 years, starting from the war with the Dutch (1873-1912), the war for independence for the Republic of Indonesia, the 1976-2005-armed conflict, Tsunami 2004. I see that the response of the Acehnese people to the global Covid-19 disaster shows that there are different visions in seeing the future direction as well as 
the collective ethos and awareness of the Acehnese people.

The public's response to Covid-19 is the main focus of current research viewed from various disciplines and perspectives. A research conducted by Mahmuddin (2020) who studied community responses based on a religious perspective. According to Mahmuddin and Syandri [2] the community responded to the efforts dealing with the Covid-19 disaster in accordance to their awareness of destiny and effort. In conclusion, there are 3 classifications related to religious concept which is the response of the community, such as Qadariyah, Jabariyah and Ahlussunah Waljamaah.

Covid-19 is a challenge as well as a threat to people's lives not only results in crises in all lines of life as well as the Indonesian people generally. As stated by Nastain [3], he views that the communal community is indeed ignorant of various calls and protocols for the prevention and spread of Covid-19, according to him there are various actions that are born by the community related to how traditions or habits, economic factors, and eschatological views of This world.

As one of the most interesting themes, Covid-19 is a phenomenon that provides opportunities for sociocultural researchers to collect data directly. So that various portraits related to public and community responses in the face of Covid-19 are one of the interesting themes. Apart from Mahmuddin and Syandri [2], Nastain [3], many socio-cultural researchers have also recorded how people (Indonesia citizen) respond to Covid-19 according to the limits of each person's ability.

Apart from public response, efforts to capture state response is also interesting. As written by Harirah and Rizaldi [4] regarding the reasoning of state policies in dealing with the Covid-19 Pandemic. He assumes that the public response to state policies is determined by social class and the ability to withstand the impacts caused by the pandemic.

Anthropologically, various records related to disasters and how humans respond to them have long been recorded by people who were lucky to have the opportunity to write ethnographies about disasters. As has been written by Irwan Abdullah [1] disaster begins to get a response to become a scientific symptom that must be studied both socially, humanities and natural phenomena. However, anthropology itself only started in 1950, this study began in 1950 when Firth was doing field research and accidentally there was a disaster (Abdullah; 2006, 4).

In general, as stated by Palsson, 2004; Descola and Palsson, 2004) via Abdullah [1, p. 4] that the task of anthropology as a scientific discipline is to see the determinant conditions of human relations with the environment. Among those three forces described by Descola and Palsson (2004), I am at the same level as the efforts made by Abdullah [1, p. 4] that the relationship between nature and humans always takes place dialectically and the relationship between the two is an effort to maintain existence (space and time) of man himself.

Thus, in this article, based on the development of studies related to disasters and the relationship between humans and nature in a cultural perspective, I would like to see how disasters which were sudden events were finally responded by the people in Aceh and specifically in Lhokseumawe City, dealing with behavior and how to behave individually and institutionally.

This means that by using the diachronic data, I will see how the different responses of the Acehnese people are in the effort to deal with the Covid-19 disaster. I use this distinctive response to show that the Acehnese people are in a state of confusion, uncertainty, and a loss of collective ethos that occurs as a result of the continuous impact due to disasters that continue to hit their lives.

\section{METHOD}

I use ethnographic methods in the process of data collection and data analysis. In simple terms, ethnography can be understood as a holistic data collection process that correspond the reality as it is and seeks to explain this reality with an understandable description or thick description [5, p. 87], [6, p. 18]. This study aims to describe holistically about the response of the Acehnese people regarding the efforts to deal with the Covid-19 pandemic both personally and institutionally.

In this study, I am a key instrument for seeing, feeling and analysing various facts that exist where I live and carry out activities during the Covid-19 pandemic. In particular, the data I collect is more from the chats and actions taken by everyone I meet both in person and digitally.

\section{RESULT AND DISCUSSION}

\subsubsection{AINAL MARDHIAH; VISION ON WAR AGAINST THE DUTCH}

The effort to record how the community responds from a cultural perspective is one way to strengthen the assumption that local knowledge related to mitigation and reconstruction of life before and after a disaster is important. This means that the writing of this article is also an effort to see disasters as social symptoms that impact individual and institutional behavior as symptoms that will continue and recur. As stated by Smit (2003: 97) in Abdullah [1, P. 4] that "They are part 
of nature, have happened in the past and will happen again."

One of the local knowledge that has become a behavioristic response in an effort to fight social disasters, namely war, has existed in the people of Aceh. In the war against the Dutch, one of the Acehnese scholar wrote an imaginative story related to why the Acehnese people had to fight and what they would get. The story has become historical which was later named Hikayat Prang Sabil.

Hikayat Prang Sabil (HPS) is one of the old literary works popular among the people of Aceh. As one of the literary works specifically written as a means of preaching to raise the spirit of war of the Acehnese people against the infidels of the Netherlands. As a literary work, Hikayat Prang Sabil (HPS) is still a reflection or enrichment of experiences and hopes for how life and life work, coupled with imagination and creations supported by observations and intuition of life [7, p. 77]. However, this literary work was very valuable to the Acehnese and was also greatly feared by the Dutch when the Aceh-Dutch War was still taking place in the period 1873-1902. As commented by one of the Dutch anthropologists named Dr. A.J. Piekar when delivering a scientific oration at Syiah Kuala University, he commented on the publication of the book Hikayat Prang Sabi as the spirit of war so as not to arouse the spirit of war, but only as a historical document as a memory of a dark period in the past $[8, \mathrm{p} .21]$

As a literary work, Hikayat was not born without reasons, as stated by T. Imran Abdullah [9, p. 239] that the writing of HPS was motivated by the Dutch aggression against Aceh which occurred on December 9, 1873, after Sultan Aceh evacuated himself and died. because of the cholera epidemic, the Dutch proclaimed to the outside world that they had occupied the kingdom and controlled most of Aceh Besar. However, the Dutch did not realize that the Kingdom of Aceh and its people were like two different sides of a coin. Even though the sultan had died and the kingdom was seized, not all Acehnese people recognized this, meaning that sovereignty was not a mere symbolic issue. So many Acehnese began to fight led by the ulama.

Although HPS was feared in Dutch circles because of the "sanctifying" attitude shown by the Acehnese, it showed that HPS was a literary work that could be classified as a myth. As stated by Heddy Shri AhimsaPutra the term myth usually reminds a person of something strange and strange and irrational, but even so, there are also myths who consider it lucky, holy and sacred. In addition to the popular, 'sacred', 'sacred' HPS, HPS as a literary work also contains several stories about the heroic stories of warriors in the path of Allah and getting the best rewards in the world and the hereafter, HPS can also be classified as a myth for background reasons behind the writing of the HPS.
Ali Hasjmy [8, pp. 46-51] said that the background of the writing of HPS was the appeal for resistance raised by the ulama after the fall of the Aceh kingdom. A scholar named Tgk Tjhik Pante Kulu is the author of HPS, where HPS is dedicated specifically to the extension of the Aceh kingdom, namely his own friend named Tgk Chik Di Tiro. Tgk Tjhik Pante Kulu who is a clever and clever man who crosses his way in seeking knowledge to the land of Makkah. After hearing that Aceh was raging war, Tgk Tjhik Pante Kulu was immediately determined to return home and help his friends to fight against the Dutch infidels. On the way home, on a boat between Jeddah and Penang, HPS was composed by Tgk Tjhik Pante Kulu as his contribution to arousing the spirit of jihad against the Dutch.

The story of Ainul Mardhiah is a fictional story whose core story is based on the teachings of the source of Islamic law, namely the Al-Quran and Al-Hadith. It happened in the era of Madina, when the Prophet had moved the center of the struggle of the Muslims from Mecca to Yathrib, which later changed its name to Medina, which was also the capital of the Islamic State Daulah Islamiyah.

This story sparked the enthusiasm of the Aceh fighters at that time to fight the Dutch. Carefully the stories in the Sabil War Hikayat are told by lifting the story of Ainal Mardhiah (a representation of the gifts that you get if you fight in the way of Allah), the story of the Elephant Troop (Representation so that the Acehnese people understand that Allah will help them if they really want to fight against the Dutch. ), The story of Sa'id Salmi (a representation of the essence of human life that those who have died with the true reward of being martyred are not dead) and finally the story of dead slaves to life again.

Among these four stories, I want to tell the story of Ainal Mardhiah alone as a representation of his queen, the nymphs that anyone who fights sincerely and sincerely for Allah will get and only hopes for the reward of being martyred. The story of Ainal Mardhiah, according to the author, is very suitable to be described as a response from Acehnese ulama at that time in response to the Social Disaster that occurred in his ancestral land.

At one time, when war was raging at the time of the Prophet, there was a scholar who gave news to the whole community about the fulfilment of the call for jihad. The cleric named Abdul Wahid, in a discussion related to Holy warfare, he explained the verses of the Koran and Hadiths to all the congregation. In between his lectures, a young man appeared asking about an explanation for the certainty of the reward of martyrs on the battlefield. With confidence after receiving an explanation, the young man registered to join jihad in the path of Allah. The name is young, the young are the orphans left by their parents with wealth. With 
enthusiasm he spent all his wealth to buy armor for himself and the other youths who do not have enough.

It was on the day that was expected, the Islamic troops led by Abdul Wahid left for the battlefield. Young man who is brave and with high morale asked to be in the front line and leave early one day. When he arrived at the resting place while waiting for the troops, he took a short rest and slept soundly.

When he woke up, he burst into tears while continuing to say the word "Ainal Mardhiah" over and over again so that his friends were confused, astonished and dumbfounded by his attitude after waking up from sleep. Finally, the Master approached him and began to ask what the hell was happening to the young man. Then Mudabelia told me that during her sleep, she apparently dreamed of meeting Ainal Mardhiah. Ainal Mardhiah is the consort of the nymphs in the garden of heaven. He walked through a beautiful garden that he had never seen before. Flowers, flowing water and the empress seemed to welcome him. He met the beautiful girls who were just as young as his passionate love peaked, but the angels said that they were only maids who accompanied the princesses of the angels in the garden. Then the young continued along the river and garden which was so beautiful until he met the princess named Ainal Mardhiah.

This encounter caused a turbulent longing in the young man's chest, as if they had promised to meet. The princess angel was the same, as if she had been waiting for a long time to talk to each other and tell romantic things. When young women wanted to touch Ainal Mardhiah, slowly using her beautiful hands Ainal Mardhiah pushed the young man's chest saying that he could only be owned by a young man who was martyred in the way of Allah. Finally Mudabelia woke up, and so she told her teacher. Then he rose, eager to head for the battlefield and greeted the enemy bravely. Then the young martyr and the desire to meet Ainal Mardhiah were achieved

\subsubsection{MASK, STICKER AND SCATTER: RESPONSE TO THE COVID-19 PANDEMIC}

In the morning of early October, I had a phone call from a colleague who teaches at a university on the island of Java. Through the line, he asked about me at this time. What a surprise when he found out that I was enjoying relaxing in a coffee shop that was congested asking, "Are you not afraid to die?" for a moment I paused and started looking for answers as an excuse that here (red; Aceh) it seems that Covid-19 is less of a problem than anything else. The talk we had that morning made me flinch and start thinking as I saw people around me who did not really care about the various discourses related to today's Covid-19 news in the mass media as well as the information displayed on banners, posters, good newspapers. print or digital.
It seems he has some truth in what he said, that is it true that I am not afraid to die? Because according to current information and knowledge, I know that Covid19 has not found a cure and its spread has paralyzed people's lives globally. In Aceh itself, data shows that there is no sign that Covid-19 will decline, such as the data displayed on Covid19.go.id that to date there are 7373 confirmed cases or around $1.8 \%$ nationally.

However, statistics are just statistics, and during the data collection process, I rarely get conversations regarding the condition of Covid-19 today and informants are reluctant to talk about anything related to Covid-19 and even tend to doubt the results of the recent diagnosis. The paradox of public response regarding Covid-19 reporting is not new after Eid alFitr, some people with religious beliefs consider Eid to be a momentum that Covid-19 also ends after fasting for a full month, as all faded sins have been forgiven by Allah SWT . So it is not surprising, until mid-May 2020, Aceh is still a green area where the spread of Covid-19 can even be reduced to zero. However, after that, Aceh became a red area which was ranked 3rd in patients who were confirmed positive for Covid-19 throughout Indonesia.

The confusion in people's behavior is coming along with reasons. As a preacher Friday told about his opinion regarding the paradox of crowd enforcement that sometimes still occurs. According to him, local governments, which represent the state, are still unable to distinguish between crowds that have positive values and crowds that only spend time with useless activities. He once said, "Will Covid-19 only affect people who pray? The person who performs the Maulid? But not at a coffee shop? Shopping places and tourist attractions? "

In addition, people seem reluctant to implement health protocols. Even though Covid-19 is easy enough to reduce the spread as the treatment process continues. In various public places I often get appeals in order to deal with the Covid 19 pandemic, namely by doing $3 \mathrm{M}$ (masks, washing hands and maintaining distance) and 3 $\mathrm{T}$ (Test, Tracing and Treatment) [10].

However, appeals remain as appeals without actually becoming an information base that influences people's behavior. Even today, many people still ignore health protocols. This is as written by Harirah and Rizaldi [4] that the state and society have their own rationality for the various responses they produce. Rationality is very dependent on economic factors and social status of a person. And according to their religious knowledge [2].

Likewise, with the response of the Aceh government and several district municipal governments in Aceh. Various policies issued are counterproductive to the conditions of the Covid-19 pandemic. Of the various efforts recommended by the Ministry of Health of the Republic of Indonesia [10] related to the guidelines for 
the prevention and control of Coronavirus Disease (Covid-19), namely to activate both PCR and Rapid tests, carry out tracing with close contacts of confirmed patients and carry out treatment for patients who have symptoms of illness and have a history of ill health (comorbid) are also not maximized.

In general, during the Covid-19 pandemic there were 3 main things that often became a conversation among the people of Aceh. The conversation is a response to various things they know from the reality they face. If in the past the people of Aceh responded to social disasters, namely war with high religious motivation through the saga prang sabil, then now the Acehnese are busy with 3 main things as their active response in order to resolve various confusion, insecurities and confusion as a result of various conditions caused by Covid- 19 . Namely masks, stickers and scatter that represent the personal and institutional responses.

In mid-September 2020, I met an anthropology student at a coffee shop in Lhokseumawe, it was our first meeting since the first patient suspect Covid-19 was confirmed to the public at the end of March 2020. He told me when I asked his response regarding what is happening in the people of Aceh at this time. According to him, "saat nyoe pak ureung Aceh 3 boh sagai geusemike nyangkeuh masker, stiker dan scatter". Masks are a representation of the Covid-19 pandemic as a state response to efforts to control the spread through cross-institutional raids, distribution of masks, and dissemination of information through social media. However, to this day, whether due to my own limited social relations, I have only received 1 mask from the institution where I teach, the rest have to buy and make cloth masks myself.

The second representation that we can see from the dynamics that occurred in Aceh during the Covid-19 pandemic is a sticker. The sticker for the first time became a trending issue when the Aceh government issued a regulation restricting the purchase of subsidized fuel by attaching stickers to cars as a sign that they were entitled to subsidized fuel. Eventually various communities began to respond with various tones of disappointment, amazement and occasionally showing anger on various social media platforms and other media. Like one preacher who said "what is wrong with the people of Aceh so that only in Aceh the use of subsidized fuel must be marked with a sticker on a car that does not belong to the government?". Likewise with the action by various communities which eventually stuck people's ownership stickers on various official cars with red plates owned by the Aceh government.

Finally, another social symptom that represents the response of the Acehnese people is one of the slot games that have begun to reach various ages and are often played in coffee shops, both personally and in groups. The Higgs Domino game, which was originally only a game in exchange for credit, has finally become a game that is not to be used when there is free time. The game marks itself as one of the games with elite symbols such as the use of the term 'alms' when someone plays the game in the mode of taking bonus coins. In addition, this game has become one of the introductory motives for combining expectations in something that cannot be measured, meaning that it submits itself to an uncertainty based on the terminology of "hockey" which is currently being introduced in everyday speech. The introduction of slot games will bring players to a more original game mode where the images and games are exactly the same, both mediated by coins and mediated by cash.

One of the saga of a player shared on a social media platform shows that their attention to luck is no longer based on the ethos and collective consciousness of the Acehnese people. This is when compared to the Hikayat Prang Sabil with various stories that arouse fighting spirit in the way of Allah.

The saga about scatter is sung in Acehnese style with the following sound:

"watee malam yok scatter hai kawan, jak bak dragon hek kapreh meu dibi han, pinah meja bak fafa yak bek mumang, ek sigee dibri jackpot lansung menang."

Meaning:

At night, let's scatter us friends, play in the dragon slot, we wait for a long time and haven't had any luck, then move the table to the fafa slot so we don't get dizzy, once a round wins the jackpot ".

Of the 3 representations that can be classified as the response of the Acehnese people, both personal and institutional, it can be seen in a comparative way with how the response when facing social disasters in the form of war against the Dutch during the struggle for independence long ago.

\section{CONCLUSION}

In my point of view, there are a number of conclusions that I reflect based on the facts and data that I have collected regarding the response of the state, market and community regarding the Covid-19 pandemic.

First, the response of the community and local government institutionally shows that there is confusion, uncertainty regarding the future imagined by the Acehnese people regarding what will happen after Covid-19 passes. The loss of the power of imagination that connects the life of the world and the hereafter is one of the impacts of the long history of various disasters that have been felt by the people of Aceh. 
Second, I conclude that stakeholders are stuck with a symbolic and structural approach that prioritizes numbers as determinants of policy in handling Covid-19 by forgetting the quality of the principle of dealing with the Covid-19 pandemic.

Third, the development of massive and massive domino higss games in the eyes of researchers shows that the flow of global communication is inevitable, which means that from a cultural perspective, currently the infrastructure to accelerate progress must be considered carefully.

Fourth, cultural preservation efforts are not paid attention, especially on the aspect of ideas as forming behavior. This includes countering foreign cultures which are feared to give fundamental changes to the work ethic or determinant cultural elements of Acehnese society. This means that the acculturation process that occurs due to the formation of extraordinary access and availability of time due to the pandemic causes a change in the human spirit of the Acehnese people.

\section{REFERENCES}

[1] I. Abdullah, "Dialektika Natur, Kultur, dan Struktur: Analisis Konteks, Proses dan Ranah dalam Konstruksi Bencana,” 2006.

[2] R. Mahmuddin and Syandri, "Qadariyah, Jabariyah dan Ahlussunah (Studi Komparatif Merespon Kebijakan Pemerintah dan Fatwa MUI dalam Mencegah Penularan Covid-19)," Bustanul Fuqaha; J. Bid. Huk. Islam, vol. 1, no. 2, pp. 209-222, 2020.

[3] N. S. Nastain, "Tantangan Masyarakat Komunal dalam Menghadapi Pandemi Covid-19," in Covid-19 dalam Ragam Tinjauan Perspektif., Yogyakarta: Mbridge Press, 2020.

[4] Z. Harirah and R. Annas, "Merespon Nalar kebijakan Negara Dalam Menangani Pandemi Covid-19 di Indonesia," J. Ekon. dan Kebijak. Publik, vol. 7, no. 1, pp. 36-53, 2020.

[5] Mely G. Tan, "Masalah Perencanaan Penelitian," in Metode- Metode Penelitian Masyarakat, Jakarta: Gramedia Pustaka Utama, 1991.

[6] S. Faisal, Fotmat-Format Penelitian Sosial. Jakarta: Rajawali Press, 1989.

[7] K. Djojosuroto, Analisis Teks Sastra dan pengajarannya, I. Yogyakarta: Pustaka, 2006.

A. Hasjmy, Apa Sebab Rakyat Aceh Sanggup
Berperang Puluhan Tahun Melawan Belanda. Jakarta: Bulan Bintang, 1977.

[9] I. T. Abdullah, "Ulama dan Hikayat Perang Sabil dalam perang Belanda Aceh," Humaniora, vol. 12, no. 3, 2000 .

[10] Kementerian Kesehatan Republik Indonesia, "Pedoman Pencegahan dan Pengendalian Coronavirus Disease (Covid-19),” 2020. 